\title{
PROSES ENKULTURASI DALAM BUDAYA ENTAS-ENTAS, PRASWALA GARA, DAN PUJAN KAPAT (SISTEM SOSIAL LOKAL:ANTAR ETNIS KABUPATEN PROBOLINGGO)
}

\section{ENCULTURATION OF PROCESS IN CULTURE ENTAS - ENTAS, PRASWALA GARA , AND PUJAN KAPAT ( LOCAL SOCIAL SYSTEM : INTER- ETHNIC DISTRICT PROBOLINGGO )}

\author{
AA Kusumadinata ${ }^{1 a}$ \\ ${ }^{1}$ Dosen Program Studi Komunikasi, Fakultas Ilmu Sosial dan Ilmu Politik, Universitas Djuanda Bogor, Jl. Tol \\ Ciawi No.1 Kotak Pos 35 Bogor 16720 \\ a Korespondensi: Ali Alamsyah Kusumadinata, Email: alialamsyahkusumadinata@gmail.com \\ (Diterima: 07-12-2014; Ditelaah: 10-01-2015; Disetujui: 14-01-2015)
}

\begin{abstract}
Tengger community has an interesting and unique culture which is still well preserved. Despite strong influencing eksternal factors (high intensity of tourism activities) some traditions still preserved well, some of which are Entas-Entas, Praswala Gara, and Pujan Kapat. These traditions prevail along with communication process and this become an interesting aspect to study. The research was Juni 2014 and to used case study, qualitatif researced. The result of the study indicates that traditional ceremonies in Tengger community are generally divided into those concerning family scope and village scope. The communication pattern practiced among the people of Tengger was a vertical one, where the leader or the respectable group had an important position and was obeyed by his people/ subordinates, which was a reflection of paternalistic culture still practiced. This kind of communication pattern can be seen in some teaching-learning process conducted both in formal and nonformal forums and in rituals concerning groups, sunctions, and position allocations.

Keywords : Communication, Tengger Comunity, learning
\end{abstract}

\begin{abstract}
Masyarakat Tengger memiliki budaya yang menarik dan unik yang masih terjaga dengan baik. Meskipun faktor eksternal yang kuat mempengaruhi ( intensitas tinggi kegiatan pariwisata ) beberapa tradisi yang masih dilestarikan dengan baik, beberapa di antaranya entas - entas , Praswala Gara , dan Pujan Kapat . Tradisi-tradisi ini berlaku bersama dengan proses komunikasi dan ini menjadi aspek yang menarik untuk belajar. Penelitian ini dilakukan pada bulan Juni 2014. Metode yang digunakan adalah studi kasus kuallitatif. Hasil penelitian menunjukkan bahwa upacara adat di masyarakat Tengger umumnya dibagi menjadi orang-orang mengenai ruang lingkup keluarga dan ruang lingkup desa . Pola komunikasi dipraktekkan di kalangan masyarakat Tengger adalah salah satu vertikal , di mana pemimpin atau kelompok terhormat memiliki posisi penting dan ditaati oleh -Nya orang / bawahan, yang merupakan refleksi dari paternalistik budaya masih dipraktekkan . Pola semacam ini komunikasi dapat dilihat dalam beberapa proses belajar-mengajar yang dilakukan baik di forum formal dan nonformal dan ritual mengenai kelompok, sunctions, dan alokasi posisi.

Kata Kunci : Komunikasi, Masyarakat Tengger, Pendidikan
\end{abstract}

Kusumadinata AA. 2015. Proses Enkulturasi Dalam Budaya Entas-Entas, Praswala Gara, Dan Pujan Kapat (Sistem Sosial Lokal: Antar Etnis Kabupaten Probolinggo). Jurnal Komunikatio 1(1): 17-29. 


\section{PENDAHULUAN}

Komunikasi memegang peran penting dalam menentukan bentuk suatu hubungan atau suatu generasi. komunikasi antarbudaya, dalam menjalin interaksi yang dicerminkan oleh sebuah konsep yang dikenal dengan mindlessness yaitu orang yang sangat percaya pada kerangka referensi yang sudah dikenal, kategori-kategori yang bersifat rutin, dan melakukan sesuatu dengan cara-cara yang sudah lazim (Toomey, 1999). Maknanya bahwa ketika melakukan kontak antrbudaya individu yang berada dalam keadaan mindless menjalankan aktifitas komunikasinya tanpa dilandasi kesadaran dalam berpikir. Ia hanya menggunakan sudut pandangnya dalam menilai dan memperlakukan orang lain. Seseorang yang mindless tidak menyadari bahwa ada perbedaan-perbedaan dalam masing-masing kelompok budaya disamping juga terdapat kesamaan-kesamaan diantara mereka. Bahwa komunikan merupakan individu-individu yang unik dan memerlukan pemahaman yang baik untuk dapat berperilaku yang tepat terhadap masing-masing individu tersebut. Konsep ini dikenal dengan emotional vulnerability, yaitu ketika seseorang berkomunikasi dengan dissimilar others, maka ia akan mengalami emotional vulnerability. Dalam arti bahwa identitas kelompok (misalnya identitas kultural) dan identitas individu (seperti sifat-sifat kepribadian) akan mempengaruhi cara-cara seseorang dalam mempersepsi, berpikir dan bertingkah laku dalam suatu lingkungan sosial (Toomey, 1999).

Beragam suku tersebut selanjutnya menyebar dan menempati wilayah Indonesia yang luas. Hal ini memungkinkan terjadinya dua suku atau lebih menempati lingkungan sosial yang sama. Kelompok suku tersebut bertemu, berinteraksi dan menciptakan hubungan sosial yang khas. Masyarakat Indonesia yang multikultural ini secara demografis maupun sosiologis potensial bagi terjadinya konflik. dalam konteks identifikasi kultur ini, dimana para anggota kelompok suku dilahirkan, dididik,dan dibesarkan dalam suatu suasana askriptif primodial suku mereka yang mengakibatkan perbedaan antara "siapa saya" dengan "siapa anda" terlihat nyata, membutuhkan komunikasi yang efketif sebagai upaya menjalin hubungan antarsuku. Hubungan yang terjalin dengan baik akan menciptakan interaksi yang efektif, sebaliknya, hubungan yang tidak baik menyebabkan interaksi tidak efektif, tidak harmonis dan pada akhirnya mengarah kepada konflik.

Tujuan pada penelitian ini adalah membahas proses enkulturasi yang merupakan artefak budaya yang dipertahankan dari genrasi ke generasi yang tetap dilestarikan dalam aktivitas bersama masyarakat Jawa Probolinggo. Keberadaan masyarakat Tengger di kawasan pegunungan Tengger diyakini sudah sangat lama, eksistensinya tetap diakui sebagai sebuah masyarakat tradisional yang teguh memegang adat tradisi nenek moyang. Dalam perkembangannya sampai saat ini masyarakat Tengger tersebar di empat Kabupaten di Propinsi Jawa Timur, yaitu: Lumajang, Pasuruan, Malang dan Probolinggo.

Masyarakat Tengger memiliki pencaharian sebagai petani serta memiliki tata kehidupan masyarakat yang teguh memegang tradisi. Salah satu masyarakat tengger berada di desa Ngadisari yang sebagian besar beragama Hindu yang berbeda dengan Hindu Dharma Bali. Perbedaan ini antara lain adalah adanya tradisi Kasada yang merupakan pengungkapkan rasa syukur mereka dengan "membuang" hasil pertanian dan peternakan ke dalam kawah Gunung Bromo di bulan Kasada. Seiring dengan berjalannya waktu maka kehidupan masyarakat Tengger juga mengalami perubahan, sebab tidak ada satupun dari masyarakat yang tidak berubah. Beberapa upacara yang masih sering dilakukan adalah upacara Entas-Entas yang khusus dilakukan untuk menyucikan atman atau roh orang-orang yang telah meninggal dunia. Biasanya dilakukan pada hari keseribu, walaupun pelaksanaannya tidak harus tepat pada hari tersebut. Roh atau atman yang disucikan itu dengan harapan agar dapat masuk surga. Selain itu dalam memasuki kehidupan baru masyarakat Tengger juga masih teguh melakukan tradisi perkawinan yang dilakukan menurut adat budaya Tengger, yaitu upacara Praswala Gara yang bertujuan untuk menghilangkan sangkala dan memohon restu agar kehidupan pengantin baru selalu mendapat kebahagiaan. Selain itu juga ada upacara pujian yang dilakukan oleh masyarakat Tengger yang bertujuan untuk memohon keselamatan bagi seluruh desa, seperti acara Pujan Kapat yang dilakukan setiap bulan keempat penanggalan Tengger. 
Upacara Entas-Entas, Praswala Gara, dan Pujan Kapat merupakan contoh tradisi yang masih dilakukan masyarakat Tengger sampai saat ini, sehingga makalah bertujuan untuk menganalisis pola komunikasi masyarakat Tengger dalam komunikasi antarbudaya dalam mensosialisasikan tradisi Entas-Entas, Praswala Gara, dan Pujan Kapat serta peluang konflik yang terdapat di dalamnya. kepada warga masyarakat dan generasi muda pada Masyarakat Tengger.

Tujuan dari artikel jurnal ini adalah bagaimana proses enkulturasi yang merupakan artefak budaya yang dipertahankan dari genrasi ke generasi yang tetap dilestarikan dalam aktivitas bersama masyarakat Jawa Probolinggo.

\section{MATERI DAN METODE}

Penelitian ini dilaksanakan di Desa Ngadisari, Kecamatan Sukapura, Kabupaten Probolinggo, propinsi Jawa Timur. Penelitian ini bersifat deskriptif kualitatif. Metode penelitian menggunakan pendekatan studi kasus pada upacara Entas-entas, Praswala Gara dan Pujan Kapat pada masyarakat Tengger Desa Ngadisari, dimana penelaahannya kepada kasus tersebut dilakukan secara intensif, mendalam, mendetail dan komprehensif. Pemilihan ketiga tradisi tersebut dikarenakan ketiganya yang sedang dilaksanakan pada saat penelitian berlangsung. Penelitian dilakukan pada bulan Juni 2014. Prinsip analisis data yang digunakan adalah dialogik atau dialektikal yang mengembangkan terjadinya dialog dan dialektika antara peneliti dan tineliti. Analisis dilakukan secara komprehensif, kontekstual dan multilevel, menempatkan peneliti sebagai aktivis/partisipan dalam proses transformasi sosial (Ruslan, 2003). Ini berarti model analisis data bersifat interaktif. Miles dan Huberman (1992) menyatakan bahwa analisis data model interaktif memiliki tiga alur kegiatan yang terjadi secara bersamaan dan bersifat siklus, yaitu reduksi data, penyajian data dan menarik kesimpulan/verifikasi (Gambar 1).
Gambar 1. Proses analisis data model interaktif Miles dan Huberman (1992).

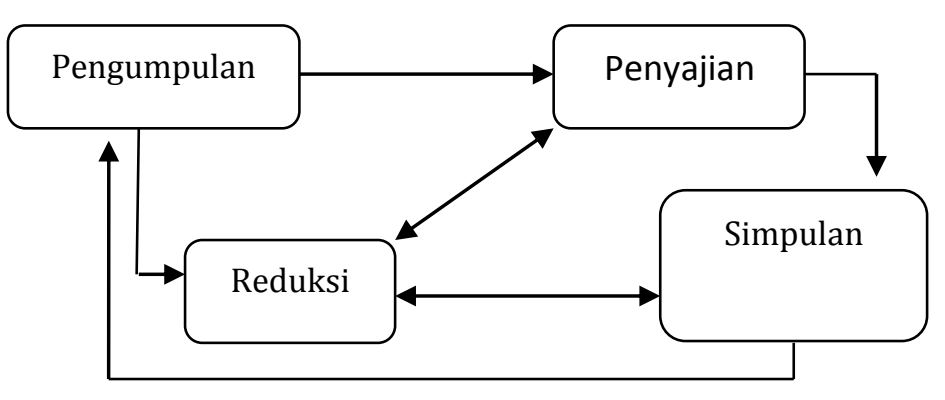

HASIL DAN PEMBAHASAN

\section{Kawasan Tengger}

Kawasan Tengger secara umum terdiri dari lembah-lembah dan lereng- lereng perbukitan yang membentang di sekitar Gunung Bromo yang merupakan sebuah gunung berapi yang masih aktif dan sepanjang tahun masih mengeluarkan asap berbau belerang dari kepundannya. Di sekeliling kepundan terdapat lautan pasir dan di sebelah Gunung Bromo terdapat sebuah gunung kecil yang bernama gunung Batok. Kawasan Tengger berada di empat kabupaten di Jawa Timur, yaitu Malang, Probolinggo, Pasuruan dan Lumajang. Pada jaman penjajahan Belanda keempat wilayah yang masuk kawasan Tengger ini merupakan daerah terisolasi, yang seolah-olah terpisah dari daerah lainnya. Pada keempat kabupaten ini terdapat 34 desa yang termasuk dalam kawasan Tengger yang tersebar di sekitar pegunungan Bromo, Tengger Semeru.

\section{Masyarakat Tengger Menurut Legenda}

Ditinjau dari arti etimologis bahasa Jawa "Tengger" berarti "berdiri tegak", diam tanpa bergerak. Apabila dikaitkan dengan kepercayaan yang hidup dalam masyarakatnya, tengger diartikan sebagai tengering budhi luhur (bahasa Jawa). Tengger berarti tanda atau ciri yang memberikan sifat khusus pada sesuatu. Dengan kata lain tengger dapat berarti "sifat-sifat budi pekerti luhur". Arti yang kedua adalah "daerah pegunungan", dimana masyarakat Tengger memang berada di lerenglereng pegunungan Tengger dan Semeru. Ada banyak versi yang menceritakan tentang legenda Gunung Bromo dan masyarakat Tengger. Versi yang pertama ini yang sudah 
sangat terkenal dan banyak ditemukan di berbagai media elektronik maupun cetak. Dalam versi ini ada yang mengatakan masyarakat Tengger sebagai pelarian dari Kerajaan Majapahit saat terjadi perebutan kekuasaan oleh orang-orang Islam yang waktu itu ingin mengubah tatanan kehidupan masyarakat Hindu Budha yang disimbolkan dengan kekuasaan Majapahit dengan tatanan Islam yang terwakili oleh kekuasaan Demak. Pada versi ini dikatakan bahwa Rara Anteng sebagai salah satu nenek moyang masyarakat Tengger merupakan putri dari Prabu Brawijaya terakhir yang memerintah Kerajaan Majapahit waktu itu.

Versi lainnya mengatakan bahwa jauh sebelum Majapahit runtuh di kawasan Tengger sudah terdapat komunitas penduduk yang hidup secara teratur. Saat terjadi keruntuhan Majapahit banyak pelarian yang menetap di daerah tersebut, namun disana sudah ada kelompok masyarakat yang hidup secara teratur. Pada versi ini pelarian dari Majapahit tersebut terdiri dari dua golongan, yaitu golongan tua dan golongan muda. Sebenarnya tujuan pelarian mereka adalah Pulau Bali, namun karena jauhnya tujuan itu, menyebabkan kelompok tersebut terpecah menjadi dua golongan. Golongan tua tinggal menetap di kawasan Tengger dengan alasan kekuatan yang sudah terbatas, sedangkan golongan muda melanjutkan perjalanan ke Pulau Bali. Pada kelompok golongan tua inilah Rara Anteng ikut dan menetap di kawasan Tengger. Sedangkan golongan muda terus ke arah timur di Pulau Bali dengan membawa semua perbekalan yang penting, seperti kitabkitab suci agama mereka. Hal inilah yang diperkirakan menyebabkan pemahaman agama hindu di kawasan Tengger agak berbeda de ngan agama Hindu Bali. Selain itu kurangnya pembinaan agama Hindu juga menyebabkan pemahaman mereka terhadap agama Hindu masih kurang. Hal ini sebagaimana yang diungkapkan oleh para peneliti dari Institut Hindu Dharma Denpasar (tahun 1982), penelitian ini pada awalnya untuk meneliti Upacara Kasada, yang pada akhirnya mereka menemukan bahwa berbagai ritual dan tradisi yang dilakukan masyarakat Tengger memiliki kesamaan dalam nilai hakikinya dengan ajaran Panca Sradha dalam ajaran Agama Hindu.

Kedua versi cerita masyarakat Tengger di atas diteruskan secara turun temurun kepada anak-anak Tengger secara lisan dari orang tua kepada generasi muda. Saat ini banyak berkembang versi tentang masyarakat Tengger, dimana sampai saat ini belum ada bukti-bukti yang kuat tentang berbagai cerita tersebut. Prasasti-prasasti yang ditemukan di Tengger justru menunjukkan angka tahun sebelum masa pelarian yang diyakini masyarakat umum, sehingga keberadaan Rara Anteng sebagai salah satu cikal bakal masyarakat Tengger sebagai keturunan Brawijaya juga sedikit diragukan. Sehingga dalam sebuah pertemuan antara seluruh dukun di kawasan Tengger, pernah terjadi suatu dialog yang pada akhirnya menghasilkan suatu keputusan tentang legenda masyarakat Tengger. Menurut para dukun Tengger yang ada cerita bahwa Rara Anteng dan Jaka Seger keduanya sama-sama anak seorang Brahmana. Menurut Undang-Undang Manawa yang berlaku di India, karena mereka keturunan Brahmana, maka masyarakat Tengger termasuk dalam golongan masyarakat dengan pelapisan masyarakat yang paling atas. Jika mengikuti pola Hinduisme tersebut, maka masyarakat Tengger menurut urut-urutan piramidal masyarakat termasuk golongan pemimpin.

\section{Masyarakat Tengger Menurut Sejarah}

Keyakinan bahwa nenek moyang orang Tengger adalah pengungsi dari Majapahit perlu dikaji ulang. Pada tahun 1880 seorang perempuan Tengger menemukan sebuah prasasti yang disebut prasasti Walandhit terbuat dari kuningan berangka tahun 1327 saka atau.sekitar 1407 Masehi di daerah Penanjakan, desa Wonokitri, kabupaten Pasuruan, telah menguak misteri tentang latar belakang historis orang Tengger. Prasasti tersebut menyebutkan bahwa sebuah desa bernama Walandhit dihuni oleh hulun hyang atau abdi dewata dan tanah di sekitar Walandhit disebut hila-hila atau suci. Warga desa Walandhit dibebaskan dari kewajiban membayar titileman, yakni pajak upacara kenegaraan karena mereka berkewajiban melakukan pemujaan terhadap Gunung Bromo. Prasasti tersebut dihadiahkan oleh Bathara Hyang Wekas ing Sukha (Hayam Wuruk) pada bulan Asada (Pigead,1962). Dengan demikian prasasti Walandhit menunjukkan bahwa kawasan Taman Nasional Bromo Tengger Semeru sudah berpenghuni sejak kerajaan Majapahit masih berjaya. Terdapat dua 
kemungkinan yang perlu dipertimbangkan untuk menemukan asal-usul orang Tengger. Pertama, meskipun orang Walandhit bukan keturunan Majapahit tetapi kegiatan beragama mereka tidak berbeda jauh atau mungkin sama dengan warga kerajaan Majapahit pada umumnya, yaitu mereka melakukan kegiatankegiatan keagamaan yang bercorak HinduBudha. Kemungkinan kedua, karena merasa seiman dan senasib sepenanggungan orang Majapahit menerima para pengungsi dari Majapahit yang terdesak oleh ekspansi daerah Islam oleh tentara Demak pada abad ke $16 \mathrm{M}$. Para pengungsi dari Majapahit tersebut kemudian menyatu dan menurunkan orang Tengger yang kita kenal sampai sekarang. Sumber lain yang memberitakan tentang Masyarakat Tengger adalah berita dari Raffles. Tengger artinya heran atau keheranan, yaitu berasal dari kata "ajeng ger". Seperti yang pernah dikemukakan oleh Raffles dalam bukunya "History Of Java", sebagai berikut:

"The people of Tengger mountains say that they received that name from a person from Mataram of an in quisstive and traveling tunn (wong malana), who having ascended the highest of them and being struck with astonishment at the view all around, gawkay them the above mantioned name of Tengger, from the Javanesse word ajeng ger, with significs wonder of astonishment"

\section{Pola Komunikasi Masyarakat Tengger}

Proses Komunikasi dalam pewarisan budaya suatu nilai budaya diwariskan dari generasi ke generasi melalui suatu proses komunikasi atau disebut dengan enkulturasi. Van Doorn dan Lammers (1959) sebagaimana yang dikutip oleh Sajogyo (1983) menyatakan bahwa cara atau proses melakukan kontrol sosial dapat dilakukan dengan: proses ajar, didik atau pewarisan (adat/pola kebudayaan), dengan sanksi pemberian hukuman atau pahala, dalam ritus kolektif dan dengan alokasi posisi-posisi. Proses pewarisan tradisi Tengger dapat diterangkan melalui:

Proses ajar, proses komunikasi ini terjadi melalui forum yang bersifat formal dan non formal.

Formal (melalui lembaga pendidikan): materi budaya Tengger dalam mata pelajaran sekolah serta dalam kegiatan Pramuka.

Proses Pengajaran di Sekolah
Proses ajar materi tentang adat dan tradisi Tengger di sekolah dilakukan bersama-sama dengan pelajaran agama Hindu maupun kewarganegaraan. Sosialisasi dan pengenalan tradisi Tengger ini mulai intensif dilakukan. Saat ini bahkan di tingkat Sekolah Menengah Pertama sudah mulai dirintis untuk membuat mata pelajaran khusus yang mengajarkan tentang tradisi Tengger. Salah satu tim yang melaksanakannya adalah Dukun Desa Ngadisari dengan pertimbangan untuk lebih memudahkan pengenalan tradisi. Sebagai Source (sumber) dalam proses pengajaran ini adalah Guru. Proses pengajarannya sama dengan pengajaran mata pelajaran umumnya, yaitu secara ceramah dan tanya jawab. Guru sebagai pengajar berfungsi sebagai pemberi informasi, proses komunikasinya dilakukan secara tatap muka dan melalui media cetak, berupa: makalah yang dibuat sendiri oleh guru. Dalam saat-saat tertentu diadakan juga praktek pemujaan di sekolah. Siswa wajib menggunakan pakaian adat saat datang ke sekolah. Pakaian adat yang digunakan oleh siswa-siswi tersebut sama dengan pakaian adat masyarakat Tengger pada umumnya. Selain itu jika ada pelajaran lain yang kemungkinan ada bersinggungan dengan kebudayaan, biasanya ikut diselipkan, misalnya sejarah dikaitan dengan sejarah Tengger.

Kegiatan Pramuka

Kegiatan Pramuka merupakan suatu wadah organisasi kepemudaan yang difasilitasi oleh pemerintah desa Ngadisari. Peserta dari kegiatan ini adala semua warga masyarakat yang sudah lulus sekolah tapi belum menikah, baik laki-laki maupun perempuan. Mereka diwajibkan mengikuti kegiatan ini dan diberi surat keterangan lulus (sertifikat) yang harus ditunjukkan kepada Kepala Desa saat mengurus surat ijin menikah. Jika belum memiliki sertifikat maka ijin menikah tidak diberikan atau jika diberi ijin maka harus ada sangsi yang diterima, yaitu mengikuti kegiatan dalam jangka waktu tertentu setelah menikah. Kegiatan ini dilakukan setiap hari Jum'at di Sanggar Pramuka desa atau di Balai Desa Ngadisari pukul 13.00 WIB sampai pukul 16.00 WIB ata sampai semua kegiatan selesai. Tujuan dari kegiatan ini adalah untuk melatih mental dan kedisiplinan generasi muda (laki-laki dan perempuan), menambah pengetahuan dan wawasan, baik tentang pengetahuan agama maupun adat budaya Tengger. Jenis-jenis pesan (message) yang disampaikan dalam kegiatan 
kepramukaan, olah raga, agama dan adat, PBB (Persatuan Baris Berbaris), Etika dan kegiatan Bakti Sosial. Materi agama dan adat sebesar dari seluruh total pertemuan yang dilakukan. Pembina utama dalam kegiatan Pramuka ini adalah Kepala Desa Ngadisari. Source (sumber pemberi informasi) dalam kegiatan Pramuka disesuaikan dengan materi yang sedang diberikan, sedangkan receiver (penerima informasi) adalah anggota Pramuka yang hadir. Jika materi agama maka yang berperan sebagai sumber informasi adalah Pinandhita, jika Etika yang bertindak sebagai source adalah Kepala Desa. Saat ini yang tercatat pernah mengisi materi (sebagai sumber informasi) dalam kegiatan ini adalah: Kepala Desa, Dukun Adat, Kepala Hansip, Pinandhita dan Kepala Urusan (Kaur) Pemerintahan Desa.

Dapat disimpulkan jika 100 persen pemberi materi adalah tokoh masyarakat, semua berjenis kelamin laki-laki. Sejak dulu belum pernah ditemui sumber informasi dalam kegiatan Pramuka seorang perempuan. Dulu jika waktu materi agama dan adat, pernah diwajibkan memakai pakaian adat, namun sekarang tidak lagi dilakukan karena alasan kepraktisan, sebab menyulitkan mereka yang rumahnya jauh dari sanggar Pramuka. Saluran komunikasi yang digunakan dalam proses pengajaran ini adalah saluran interpersonal dengan melakukan komunikasi tatap muka setiap kali pertemuan. Selain itu juga terdapat saluran komunikasi bermedia, yang ditunjukkan dengan adanya media cetak berupa makalah yang dipakai untuk memudahkan penyampaian informasi dari source (pemberi materi) kepada receiver (anggota Pramuka) yang hadir.

Proses komunikasi tersebut dapat digambarkan seperti pada Tabel 1.

Tabel 1. Prose komunikasi Formal

\begin{tabular}{|c|c|c|c|c|}
\hline & Sumber & Pesan & Saluran & Penerima \\
\hline Sekolah & Guru/pengajar & $\begin{array}{l}\text { Pengenalan } \\
\text { macam-macam } \\
\text { tradisi tengger }\end{array}$ & $\begin{array}{lr}\text { Tatap } & \text { muka } \\
\text { (langsung), } & \text { Tak } \\
\text { langsung } & \\
\text { bermedia } & \text { cetak, } \\
\text { makalah } & \end{array}$ & Murid sekolah \\
\hline Pramuka & $\begin{array}{l}\text { Kepala Desa, } \\
\text { Pinandhita }\end{array}$ & $\begin{array}{l}\text { Etika/ agama dan } \\
\text { adat }\end{array}$ & $\begin{array}{l}\text { Tatap muka } \\
\text { (langsung), Tak } \\
\text { langsung } \\
\text { bermedia cetak, } \\
\text { makalah }\end{array}$ & Pramuka \\
\hline
\end{tabular}

\section{Sumber : Data olahan (2014)}

Toomey (1999) menjelaskan bahwa komunikasi langsung dan tak langsung merupakan salah satu bentuk dari komunikasi antarbudaya. Komunikasi langsung merupakan salah satu penukaran pesan dari generasi ke generasi yang efektif dalam menyampaikan pesan sejarah. Hal ini terlihat pada budaya kolektivis yang dimiliki masyarakat Tengger yang saling terbuka. Selain itu pesan tak langsung yang menggunakan pesan non verbal sering dimanfaatkan dengan penggunaan pakaian adat, upacara dan sebagainya adalah bagian sosialisasi dari pola komunikasi yang dilakukan.
Non formal melalui proses komunikasi antar pribadi (melalui proses belajar tata cara upacara kepada yang lebih mengerti).

Proses pengajaran ini lebih bersifat non formal, sebab dilakukan pada saat persiapan upacara. Seperti pada waktu upacara EntasEntas pada malam hari sebelum pelaksanaan, di rumah Wong Sepuh membuat petra, biasanya banyak orang-orang yang ikut membantu atau sekedar melihat pembuatannya. Di sinilah terjadi proses pengajaran budaya secara non formal dengan adanya proses belajar dan transfer informasi. Sumber informasi adalah Wong Sepuh, pesan (message) yang disampaikan berupa pengetahuan bahan-bahan pembuat petra, tata cara pembuatan petra, sedangkan penerima 
informasi (receiver) adalah orang-orang yang hadir. Proses ajar dalam tradisi Praswala Gara, dapat dilihat dalam persiapan upacara. Sumber informasi (source) adalah Legen, pesan (message) yang disampaikan berupa persiapan dan pengetahuan tentang berbagai dandanan/ ubo rampe upacara, sedangkan receiver ada lah orang-orang yang bertanya. Proses komunikasi yang berlangsung biasanya secara interpersonal, melalui tatap muka. Selain itu juga ada forum pembelajaran lain secara non formal, yaitu proses belajar yang dilakukan oleh warga masyarakat secara aktif, dimana message berupa informasi tentang tradisi Tengger diperoleh dengan bertanya langsung kepada orang-orang yang dianggap lebih mengerti. Biasanya yang menjadi sumber informasi adalah dukun, legen/ mantan legen dan wong sepuh/ mantan wong sepuh. sedangkan yang menjadi receiver adalah orang-orang yang bertanya tersebut. Dukundukun yang berada di kawasan Tengger memiliki jaringan komunikasi yang cukup baik. Dukun-dukun tersebut dikoordinasi dengan baik oleh seorang koordinator dukun. Masingmasing kabupaten yang memiliki suku tengger, yaitu Malang, Pasuruan, Probolinggo dan Lumajang terdapat Koordinator Dukun. Jika ada permasalahan yang dihadapi atau sesuatu yang tidak dimengerti, biasanya dukun Desa Ngadisari, menanyakan hal tersebut pada dukun lain yang lebih senior, biasanya kepada koordinator dukun sekawasan Tengger. Di sini juga terjadi suatu transfer informasi melalui proses pengajaran secara non formal. Source (sumber informasi) adalah koordinator dukun, sedangkan receiver adalah dukun yang bertanya. proses komunikasi yang terjadi melalui saluran interpersonal secara tatap muka dan juga melalui saluran bermedia, melalui media cetak (makalah, catatan/ dokumentasi pribadi) dan media elektronik (telpon). Proses komunikasinya dapat dilihat pada Tabel 2.

Tabel 2. Prosees komunikasi dalam non Formal

\begin{tabular}{lllll}
\hline & Sumber & Pesan & Saluran & Penerima \\
\hline $\begin{array}{l}\text { Sebelum } \\
\text { Entas-Entas }\end{array}$ & Wong Sepuh & Pembuatan Petra & Tatap muka & $\begin{array}{l}\text { Orang-orang yang } \\
\text { datang }\end{array}$ \\
$\begin{array}{l}\text { Sebelum } \\
\text { Gaswala }\end{array}$ & Legen & $\begin{array}{l}\text { Pembuatan } \\
\text { macam-macam } \\
\text { dandanan/ ubo } \\
\text { rampe dalam } \\
\text { upacara, Pasrah } \\
\text { pengantin, Waktu } \\
\text { pelaksanaan dan } \\
\text { persiapan }\end{array}$ & $\begin{array}{l}\text { Orang-orang yang } \\
\text { bertanya }\end{array}$ \\
& & & \\
& & & \\
& &
\end{tabular}

\begin{tabular}{|c|c|c|c|c|}
\hline $\begin{array}{l}\text { Proses } \\
\text { belajar } \\
\text { secara aktif }\end{array}$ & $\begin{array}{l}\text { Dukun, Legen/ } \\
\text { Mantan Legen, } \\
\text { Wong } \\
\text { Sepuh/ Mantan } \\
\text { Wong Sepuh }\end{array}$ & $\begin{array}{lr}\text { Hal-hal yang } \\
\text { berkaitan } \\
\text { tradisi }\end{array}$ & $\begin{array}{l}\text { Tatap muka, } \\
\text { media cetak, tak } \\
\text { langsung }\end{array}$ & Warga masyarakat \\
\hline $\begin{array}{l}\text { Komunikasi } \\
\text { antar dukun }\end{array}$ & $\begin{array}{l}\text { Koordinator } \\
\text { dukun }\end{array}$ & $\begin{array}{l}\text { Pembahasan } \\
\text { masalah adat } \\
\text { yang dihadapi } \\
\text { masing-masing } \\
\text { Dukun di desa } \\
\text { masing-masing. }\end{array}$ & $\begin{array}{l}\text { Tatap muka, } \\
\text { Media cetak: } \\
\text { makalah, catatan/ } \\
\text { dokumentasi } \\
\text { pribadi, Media } \\
\text { elektronik }\end{array}$ & $\begin{array}{l}\text { Dukun } \\
\text { Bertanya }\end{array}$ \\
\hline
\end{tabular}

\section{Sumber : Data olahan (2014)}

Pemberian hukuman dan pahala (punishment dan reward), berupa: (a) Hukuman: berupa sanksi moral, dikucilkan dari pergaulan. Tradisi
Entas-Entas, Praswala Gara, dan Pujan Kapat di Desa Ngadisari selalu dilaksanakan oleh masyarakat Desa Ngadisari. Selama ini belum 
ada yang meninggalkan upacara ini. (b) Pahala: adanya penghargaan dan pengakuan masyarakat terhadap tingkat pengetahuan yang dimiliki (pemberian predikat sebagai orang yang paham budaya), pada tahap selanjutnya mereka dapat dicalonkan/ mencalonkan diri menjadi tokoh adat seperti legen, wong sepuh atau bahkan dicalonkan sebagai Dukun.

Ritus Kolektif pada upacara Entas-Entas, Praswala Gara, dan Pujan Kapat sebagai sebuah ritus kolektif sebenarnya memiliki makna sebagai penguat solidaritas sosial. Sebagaimana yang dikemukakan oleh seorang ahli folklor Van Gennep yang dikutip oleh Koentjaraningrat (1987) bahwa ritus dan upacara religi secara universal pada azasnya berfungsi sebagai aktivitas untuk menimbulkan kembali semangat kehidupan sosial antara warga masyarakat. Sistem ritus dan upacara dalam suatu religi berwujud aktivitas dan tindakan manusia dalam melaksanakan kebaktiannya terhadap Tuhan, dewa, roh atau makhluk halus lain dengan tujuan untuk berkomunikasi. Pada Upacara Entas-Entas sebagai sebuah upacara kematian, sebagaimana pendapat Hertz yang dikutip oleh Koentjaraningrat (1987) bahwa upacara kematian selalu dilakukan manusia dalam rangka adat-istiadat dan struktur sosial dari masyarakatnya, yang berwujud sebagai gagasan kolektif. Ritus atau upacara religi akan bersifat kosong tak bermakna, apabila tingkah laku manusia di dalamnya didasarkan pada akal rasional dan logika. Secara naluri manusia memiliki suatu emosi mistikal yang mendorongnya untuk berbakti kepada kekuatan tinggi yang olehnya tampak konkret di sekitarnya. Hal inilah yang menjadi pendorong upacara seperti Entas-Entas, Praswala Gara, dan Pujan Kapat masih selalu dilakukan. Sebagai sebuah ritus kolektif berbagai upacara tersebut selalu melibatkan banyak orang (anggota keluarga dan para tetangga), sehingga generasi muda dan warga masyarakat lainnya dapat mengikuti. Pada upacara Pujan Kapat semua warga masyarakat desa merasa ikut memiliki hajat ini, setiap rumah memberikan bantuan untuk upacara Entas-Entas, Praswala Gara maupun Pujan Kapat.

Tabel 3. Proses Komunikasi dalam Ritus Kolektif

\begin{tabular}{lllll}
\hline & Sumber & Pesan & Saluran & Penerima \\
\hline Entas-Entas & Dukun & $\begin{array}{l}\text { Persiapan Entas- } \\
\text { Entas }\end{array}$ & Tatap muka & $\begin{array}{l}\text { Keluarga yang } \\
\text { menyelenggarakan } \\
\text { entas-entas }\end{array}$ \\
$\begin{array}{l}\text { Praswala } \\
\text { Gara }\end{array}$ & Dukun & $\begin{array}{l}\text { Persiapan } \\
\text { praswala gara }\end{array}$ & Tatap muka & $\begin{array}{l}\text { Keluarga } \\
\text { menyelenggarakan } \\
\text { praswala gara }\end{array}$ \\
Pujan Kapat & Dukun & $\begin{array}{l}\text { Waktu } \\
\text { Pelaksanaan } \\
\text { Pujan } \\
\text { Kapat }\end{array}$ & $\begin{array}{l}\text { Tatap muka } \\
\text { Media cetak: } \\
\text { kalender }\end{array}$ & Masatat desa \\
& & & & \\
\hline
\end{tabular}

Sumber : Data olahan (2014)

Alokasi acara Entas-entas, Praswala gala dan Pujian Kapat merupakan Posisi, dimana ada peranan-peranan tertentu yang dilakukan sesuai dengan status yang dimilikinya. Alokasi posisi ini antara lain adalah: (a) Kuatnya Peranan Kepala Desa, dengan kewenangan yang dimiliki serta inisiatif untuk melestarikan budaya Tengger, maka Kepala Desa mensosialisasikan berbagai ketentuan adat, seperti penggunaan pakaian adat di setiap upacara. (b) Peran keluarga yang cukup besar dalam menjalin komunikasi dengan generasi muda.

Pada keluargalah pertama kali seorang anak mengetahui dan dilibatkan dalam berbagai upacara. Misalnya dalam Entas-Entas biasanya anak-anak ikut dalam upacara sebagai pemangku roh. Samovar LA, Richarrd EP \& Edwin RM (2010) keluarga adalah induk primer dalam sosialisasi yang efektif dalam penyampian pesan. Sehingga unsur keluarga yang membentuk komunikasi tahap kedua, 
ketiga dan selanjutnya. Adapun Pola komunikasi masyarakat Tengger tidak dapat terlepas dari pengaruh: (1) Kebijakan, yaitu adanya kebijakan yang dikeluarkan oleh pihakpihak yang memiliki kewenangan, antara lain: (a) Kebijakan pemerintah desa sebagai kawasan desa wisata budaya. Berbagai upaya dilakukan sebagai sarana penunjang, seperti pembangunan infrastruktur yang lebih menunjang, misalnya jalan, gerbang desa, pedanyangan (tempat pembakaran petra), kewajiban penggunaan pakaian adat di setiap upacara adat Tengger, pengenalan tradisi Tengger kepada para generasi muda agar menumbuhkan kecintaan dan kebanggaan terhadap budaya mereka. (b) Pandangan tokoh adat dan tokoh agama. Sebagai sebuah budaya warisan leluhur dan terkait dengan keyakinan mereka, maka tradisi tersebut wajib dilakukan oleh masyarakat Tengger sebagai wujud bakti kepada Yang Maha Kuasa. Hal inilah yang menjadi pendorong bagi mereka untuk terus melestarikan tradisi yang ada. Seperti tradisi Entas-Entas yang dalam agama Hindu merupakan salah satu ajaran Panca Srada untuk mencapai nirwana. (2) Sikap masyarakat juga ikut mempengaruhi pola komunikasi dalam sosialisasi tradisi tersebut. Sikap masyarakat terhadap pendidikan dan terhadap uang ikut mempengaruhi pola komunikasi dalam sosialisasi tradisi tersebut. Saat ini masyarakat Tengger sudah mulai menyadari pentingnya pendidikan, meskipun hal ini masih terbatas pada kalangan tertentu, seperti perangkat desa dan tokoh masyarakat. Adanya keinginan untuk menjadikan desa budaya dilatar belakangi juga oleh sikap terhadap uang, dimana nantinya diharapkan adanya perpaduan antara obyek wisata alam Bromo dengan obyek wisata budaya dari masyarakat Tengger mampu menambah pendapatan masyarakat. Masyarakat Tengger Desa Ngadisari merupakan masyarakat yang taat pada pemimpin, sehingga apa yang dikatakan pemimpin (dalam hal ini Kepala Desa) selalu dipatuhi. Inilah pula yang menyebabkan mereka jadi sering tergantung pada keputusan pimpinan, termasuk dalam menentukan pelaksanaan upacara Entas-Entas dan Praswala Gara. Selain itu rasa hormat pada generasi tua juga masih cukup kuat. Hal ini menyebabkan mereka patuh pada orang-orang yang lebih tua, biasanya tampak pada kehidupan keluarga, sehingga sosialisasi tradisi dalam keluarga dari generasi tua lebih mudah diterima oleh generasi muda.

Tradisi masyarakat Tengger tidak dapat lepas dariperan dukun adat yang menjadi penanggung jawab sekaligus sumber utama informasi tentang berbagai tradisi yang ada. Masing-masing desa di kawasan Tengger memiliki seorang dukun yang bertanggung jawab terhadap kegiatan adat di desa mereka. Dukun- dukun ini dikoordinir oleh seorang koordinator dukun, kemudian masing-masing kabupaten yang merupakan kawasan Tengger juga terdapat koordinator untuk mempermudah koordinasi dan penyampaian informasi, hal ini disebabkan kawasan Tengger yang cukup luas. Jika ada pertemuan biasanya koordinator dukun sekawasan Tengger yang menghubungkan koordinator dukun kabupaten, kemudian diteruskan kepada Dukun desa. Seiring dengan perkembangan teknologi informasi, sekarang lebih memudahkan komunikasi, yaitu melalui media elektronik.

Setiap dukun yanga ada di masing-masing desa di Kawasan Tengger erhubungan/ bekerja sama dengan pemimpin desa (Kepala Desa) dalam penyampaian informasi tentang budaya. Dukun merupakan staf khusus dari Kepala desa yang menangani masalah adat. Kelembagaan dan struktur organisasinya secara non formal dan bertanggung jawab secara moral atas segala tugas yang diembannya. Dukun ini dibantu oleh Legen dan Wong Sepuh. Desa Ngadisari memiliki dua Legen dan dua Wong Sepuh. Merekalah yang bertanggung jawab terhadap segala persiapan upacara. Semua informasi tentang adat dan tradisi biasanya ditanyakan kepada dukun dan para pembantunya (para kerabatnya). Dukun sendiri biasa mengkaji masalah yang dihadapi dengan membaca kembali kitab-kitab yang ada, biasa disebut Kitab Sangga Buwana yang bertuliskan Jawa, sehingga tidak semua orang dapat membacanya. Segala perintah tentang adat biasanya atas sepengetahuan dan persetujuan dukun.

Sebelum pelaksanaan upacara, khususnya upacara lingkup keluarga maka setiap yang punya hajat dapat menghubungi Kepala Desa atau Dukun, sebab keduanya saling berkoordinasi. Kepala desa yang akan mengagendakan hari pelaksanaan upacara, disesuaikan dengan urutan warga masyarakat lain yang sudah mendaftar, selain juga berdasarkan perhitungan hari baik menurut 
keyakinan mereka. Setelah itu Dukun yang akan menginformasikan segala keperluan yang harus disiapkan kepada keluarga yang punya hajat.

\section{Forum-Forum Komunikasi Masyarakat Desa Tengger}

Forum-forum pertemuan antara warga masyarakat desa Ngadisari dapat diterangkan sebagai berikut:

1. Pertemuan Rukun Tetangga (RT).

Pertemuan warga RT ini biasanya dilakukan setiap tiga bulan sekali di masing-masing RT yang dihadiri pula oleh Kepala Desa serta perangkatnya. Tujuan pertemuan ini adalah untuk mengkomunikasikan semua program pembangunan desa. Disamping itu juga merupakan forum untuk sharing, dengar pendapat dengan masyarakat dan para perangkatnya. Diharapkan evaluasi program pembangunan desa dapat dilakukan oleh semua masyarakat dan partisipasi masyarakat dalam memberikan saran dan masukan yang dapat dilakukan di sini. Pertemuan ini biasanya bertempat di rumah ketua RT atau juga menggunakan kantor dusun untuk mendekatkan anak-anak sekolah yang rumahnya jauh dari gedung pusat.

\section{Pertemuan Ibu-ibu PKK.}

Pertemuan Ibu-ibu PKK dilaksanakan setiap bulan bertempat di panti PKK Balai Desa Ngadisari. Tujuan pertemuan ini adalah untuk menambah wawasan para Ibu-ibu tentang berbagai hal yang berkaitan dengan kesejahteraan keluarga.

\section{Puskesmas keliling}

Setiap tanggal 15 di balai dusun dikunjungi oleh dinas kesehatan yang bertujuan untuk memeriksa kesehatan warga masyarakat. Pemerikasaan kesehatan ini termasuk murah dan terjangkau oleh masyarakat, biasanya cukup dengan membayar Rp. 2000,- untuk sekali periksa. Disamping itu juga dilakukan penimbangan balita dan para lansia yang bertujuan untuk melihat tingkat kesehatan mereka. Selain itu juga sebagai upaya deteksi awal terhadap penyakit yang mungkin menyerang.

\section{Pertemuan yang bersifat insidental.}

Pertemuan ini diadakan secara insidental, jika ada suatu program pemerintah yang harus disosialisasikan, maka pemerintah desa segera mengadakan pertemuan dengan warga di Balai Desa. Proses Komunikasi Secara Non-Verbal Berbagai upacara masyarakat Tengger dilakukan untuk memenuhi fungsi komunikasi yang berupa komunikasi ritual. Sesuai pendapat Gorden yang dikutip oleh Mulyana (2001) bahwa komunikasi ritual biasanya dilakukan secara kolektif. Suatu komunitas sering melakukan upacara-upacara berlainan sepanjang tahun dan sepanjang hidup, yang disebut para antropolog sebagai rites of passage , mulai dari upacara kelahiran, sunatan, ulang tahun, pertunangan, per kawinan hingga upacara kematian, sebagaimana upacara Entas-Entas, Praswala Gara, dan Pujan Kapat yang dilakukan masyarakat Tengger. Pada pelaksanaan acaraacara itu orang mengucapkan kata -kata atau menampilkan perilaku-perilaku tertentu yang bersifat simbolik (biasa disebut komunikasi non verbal).

Komunikasi non verbal sebagaimana yang dikatakan Sobur (2004) adalah komunikasi tanpa bahasa atau komunikasi tanpa kata, maka tanda non verbal berarti tanda minus bahasa atau tanda minus kata. Secara sederhana, tanda non verbal dapat diartikan semua tanda yang bukan kata-kata. Tandatanda non verbal dalam upacara masyarakat Tengger termasuk tanda yang ditimbulkan oleh manusia, dapat bersifat verbal dan non verbal. Yang bersifat verbal adalah tandatanda yang digunakan sebagai alat komunikasi yang dihasilkan oleh alat bicara.

Sedangkan yang bersifat nonnerbal dalam makalah ini berupa gerakan tubuh, benda benda/ simbol-simbol/ atribut yang bemakna kultural dan ritual, yaitu: (1) Seorang laki-laki yang memakai baju putih, bawahan hitam, kain sarung dan udeng, dilengkapi dengan sampet (selendang berwarna kuning yang disilangkan di depan dada), mengkomunikasikan bahwa dia adalah seorang dukun yang akan memimpin upacara adat Tengger. Hal yang menjadi penanda utama dalam penyampaian pesan secara non verbal bahwa dia seorang dukun adalah baju putih dan sampet berwarna kuning. (2) Seorang dukun dengan pakaian lengkap seperti di atas ditambah dengan memakai kain cinde panca warna secara menyilang di depan dada (biasanya dipakai menumpuk dengan sampet), maka dapat diketahui secara pasti bahwa upacara yang dipimpin adalah upacara Entas-Entas. Penanda non verbal yang digunakan adalah kain cinde 
panca warna, sebab hanya dipakai khusus dalam pelaksanaan upacara Entas-Entas. (3) Upacara masyarakat Tengger selalu menghadap ke arah Gunung Bromo (arah selatan). Pesan yang disampaikan dari komunikasi non verbal ini adalah menginformasikan bahwa kiblat mereka adalah Gunung Bromo yang diyakini sebagai manifestasi dari Padmasana, yaitu sebagai pelinggih/ singgasana dari Sang Hyang Widi Wasa. (4) Orang perempuan berpakaian rapi membawa beras, gula atau bahan-bahan lain dengan cara digendhong (memakai selendang), maka dapat ditangkap sebuah pesan bahwa dia akan pergi ke tempat orang yang sedang punya hajat, seperti menghadiri upacara Entas-Entas, Praswala Gara atau upacara lingkup keluarga yang lain dalam tradisi masyarakat Tengger. Sebagai penanda dalam komunikasi non verbal ini adalah gendhongan (selendang) yang dibawa. (5) Dalam suatu upacara adat lingkup keluarga (Entas-Entas atau Praswala Gara), terdapat orang laki-laki atau perempuan yang memakai pakaian adat (baju hitam). Pakaian yang mereka gunakan merupakan pesan secara non verbal bahwa mereka adalah yang punya hajat.

Semua orang biasanya akan langsung mengenali mereka dengan pesan tersebut. Penanda komunikasi non verbal yang tampak adalah penggunaan pakaian adat, sebab aturan dan kebiasaan dalam upacara lingkup keluarga di desa ini, bagi yang punya hajat wajib memakai pakaian adat agar mudah dikenali. (6) Laki-laki yang berkeliling dari rumah ke rumah untuk menginformasikan pelaksanaan upacara Pujan. Biasa berjalan kaki dengan membawa karung beras yang dipanggul di atas pundak, waktunya biasanya pada sore hingga menjelang malam hari, mengkomunikasikan bahwa dia seorang Legen yang sedang melakukan uwar/ mupu sebelum pelaksanaan upacara Pujan. Penanda non verbalnya berupa karung beras yang dibawa di atas pundak, sebab biasanya masyarakat jika berbelanja menggunakan kain sarung atau kawengnya sebagai tempat untuk membawa berbagai belanjaan termasuk beras. Saat melihat dari jauh, masyarakat sudah dapat menduga bahwa mereka sedang melakukan uwar, sehingga mereka dengan sengaja menunggu di rumah. (7) Saat Dukun duduk bersedekap di depan petra yang telah bersaji sambil berkomat-kamit (orang lain hanya melihat mulutnya bergerakgerak seperti membaca sesuatu, namun tidak terdengar/ tidak jelas apa yang dibacanya), menunjukkan bahwa suatu upacara akan segera dimulai. Makna dari ritual yang dilakukan oleh dukun tersebut adalah nglungguhen (mempersilahkan) para roh leluhur untuk masuk dan menempati petra yang sudah disediakan. Penanda komunikasi nonverbalnya adalah duduk bersedekap menghadap petra. Pesan secara non verbal ini biasanya akan diikuti oleh para peserta upacara dengan segera mempersiapkan diri.

Tradisi masyarakat Tengger, khususnya upacara Entas-Entas, Praswala Gara, dan Pujan Kapat disosialisasikan melalui proses komunikasi. Proses tersebut dapat melalui proses ajar didik atau pewarisan (adat/pola kebudayaan), dengan sanksi (pemberian hukuman atau pahala ), dalam ritus kolektif dan dengan alokasi posisi-posisi. Proses komunikasi yang dilakukan melalui proses ajar didik ini dilakukan pada forum-forum yang bersifat formal dan non formal. Pada forum formal proses komunikasi dalam sosialisasi tradisi tersebut berlangsung di sekolah-sekolah (Sekolah Dasar dan Se kolah Menengah Pertama) yang ada di desa tersebut. Proses komunikasinya berlangsung sebagaimana proses pengajaran mata pelajaran sekolah, dimana sebagai sumber informasinya adalah guru pengajar. Selain itu juga dilakukan dalam kegiatan Pramuka dengan sumber informasi tentang tradisi adalah Dukun dan Pinandhita.

Pada forum non formal proses komunikasi dalam proses ajar didik terjadi saat persiapan pelaksanaan upacara Entas-Entas, Praswala Gara, dan Pujan Kapat. Sumber informasinya adalah Dukun dan para kerabatnya serta para orang tua yang lebih mengerti. Selama ini belum pernah ditemui warga masyarakat yang meninggalkan upacara tersebut, namun jika ada sanksi yang diberikan lebih bersifat moral, yaitu dikucilkan dari pergaulan. Sebab homogenitas masih dijunjung tinggi oleh komunitas ini, yang bertujuan untuk memperkuat solidaritas sesama warga. Reward/ penghargaan biasa diberikan kepada orang-orang yang lebih paham terhadap budaya. Biasanya mereka akan diangkat menjadi tokoh adat, seperti Legen, Wong Sepuh atau bahkan dukun. Pelaksanaan ritus kolektif lebih bersifat untuk memperkuat solidaritas sosial, dimana sebagai tokoh sentral sumber informasi adat dan tradisi adalah dukun, sedangkan tokoh sentral dalam pengambil kebijakan tentang tradisi adalah Kepala Desa 
yang berfungsi sebagai pemangku adat. Kuatnya budaya paternalistik menyebabkan jalur informasi lebih dominan bersifat vertikal, dengan sumber informasi terfokus pada tokoh sentral di masyarakat (Dukun dan Kepala Desa). Proses komunikasi tersebut membentuk suatu pola komunikasi vertikal yang lebih berorientasi kepada sumber informasi dan memiliki kecenderungan untuk selalu diterima dan dipatuhi oleh masyarakat sebagai penerima informasi.

Pola komunikasi seperti ini juga terbawa pada kehidupan di keluarga dimana peran keluarga (khususnya generasi tua) lebih dominan sebagai sumber informasi yang harus dipatuhi, khususnya tentang berbagai hal yang terkait dengan tradisi. Budaya paternalistik biasa terjadi pada kehidupan masyarakat desa, sebagaimana halnya dengan masyarakat Tengger. Namun yang membedakan adalah adanya dukun adat sebagai staf non formal dari kepala desa yang khusus bertanggung jawab terhadap masalah adat. Dukun ini akan tetap menjabat (biasanya sampai meninggal) meskipun Kepala Desa sudah berganti berkalikali.

Adapun tingkat konflik yang dapat terjadi lebih kecil dibandingkan masyarakat yang terbuka. Masyarakat tengger menganut sistem tertutup dengan budaya kolektivis dan kokeltivis serta budaya konteks yang tinggi dimana masyarakat mempercayakan informasi melalui kepala desa meskipun arus informasi yang terjadi secara terbuka. Selain itu masyarakat ditanamkan secara mengakar kepercayaan dari keluarga serta leluhur dengan intensitas yang tinggi oleh sistem budaya.

\section{KESIMPULAN DAN SARAN}

\section{Kesimpulan}

Upacara Entas-Entas, Praswala Gara, dan Pujan Kapat merupakan tadisi masyarakat Tengger yang sampai sekarang masih selalu dilaksanakan, hal ini berkaitan dengan upaya mereka untuk terus melestarikan tradisi ini. Upacara Entas-Entas merupakan upacara yang dilakukan untuk menyempurnakan atman atau roh orang yang sudah meninggal agar cepat mencapai nirwana. Upacara Praswala Gara adalah upacara perkawinan yang dilakukan dengan memakai tradisi Tengger. Upacara
Entas-Entas maupun Praswala Para merupakan jenis upacara adat lingkup keluarga, sehingga yang bertanggung jawab dalam persiapan dan pelaksanaan adalah pribadi keluarga yang memiliki hajat. Upacara Pujan Kapat merupakan jenis upacara adat dengan lingkup desa, sehingga menjadi tanggung jawab bersama seluruh desa yang diwakili oleh para perangkat desa dan dukun adat.

Pola komunikasi yang terdapat dalam masyarakat Tengger berupa pola komunikasi yang bersifat vertikal, dimana pemimpin atau golongan yang dihormati mendapat posisi penting dan dipatuhi oleh masyarakatnya akibat pengaruh budaya paternalistik yang masih berkembang. Pola komunikasi ini dapat dilihat dari proses ajar didik yang dilakukan pada forum yang bersifat formal maupun non formal, dalam ritus kolektif, sanksi dan alokasialokasi posisi. Dalam proses ajar didik peranan sumber informasi lebih dominan dalam proses komunikasi yang berlangsung. Ada beberapa faktor yang menyebabkan pola komunikasi seperti ini, yaitu: kuatnya peranan pemimpin (Kepala Desa), masih tingginya kepatuhan dan kepercayaan terhadap dukun adat, masih rendahnya tingkat pendidikan masyarakat Tengger dan adanya peran lembaga formal di bidang pendidikan. Pola komunikasi seperti ini terbawa juga dalam kehidupan keluarga, dimana peran keluarga cukup besar dalam menjalin komunikasi dengan generasi muda, yang disebabkan oleh masih kuatnya sikap penghargaan atau penghormatan pada generasi yang lebih tua.

\section{Saran}

Pola komunikasi yang terdapat dalam masyarakat Tengger perlu diperluas pada wilayah publik dengan menggunakan media yang berteknologi. Sehingga banyak dapat mengikuti perkembangan zaman, selain itu perlunya penelitian selanjutnya akan melihat faktor yang terkait dengan enkulturasi yang terjadi di masyarakat Tengger.

\section{DAFTAR PUSTAKA}

Berlo DK. 1960. The Process of Communication. New York: Holt, Rinehart and Winston.

Devito JA. 1997. Komunikasi Antar Manusia. Suatu Pengantar. Jakarta: Proffesional Books. 
Goldberg, Larson. 1985. Komunikasi Kelompok. Proses-proses Diskusi dan Penerapannya, diterjemahkan oleh Koesdarini Soemiati dan Gary R Jusup. Jakarta. UI Press.

Gudykunst WB. 2003. Cross Cultural and Intercultural Communication. London: Sage Publication Ltd.

Koentjaraningrat. 1994. Kebudayaan Mentalitas dan Pembangunan. Jakarta: Gramedia Pustaka Utama.

Kolopaking LM, dkk. 2003 Sosiologi Umum. Bogor: Jurusan Sosial Ekonomi Pertanian. Fakultas Pertanian. Institut Pertanian Bogor.

Miles MB\& Huberman MA. 1992. Analisis Data Kualitatif: Buku Sumber Tentang Metodemetode Baru. Jakarta: Penerbit Universitas Indonesia (UI-PRESS).

Mulyana D. 2001. Ilmu Komunikasi. Suatu Pengantar. Bandung: Remaja Rosdakarya.

Mulyana D, Rakhmat J. 2001. Komunikasi Antar Budaya. Panduan Berkomunikasi Dengan Orang-orang Berbeda Budaya. Bandung: Remaja Rosdakarya.

Ruslan, R. 2003. Metode Penelitian Public Relations dan Komunikasi. PT RajaGrafindo Persada, Jakarta.

Samovar LA, Richarrd EP \& Edwin RM. 2010. Komunikasi Lintas Budaya. Jakarta: Salemba Humanika.

Sajogyo, Sajogyo P. 1983. Sosiologi Pedesaan. Yogyakarta: Gadjah Mada University Press.

Sobur A. 2004. Semiotika Komunikasi. Bandung: Remaja Rosdakarya.

Soekanto S. 1990. Sosiologi Suatu Pengantar. Jakarta: PT Raja Grafindo Persada.

Toomey ST. 1999. Communication Across Cultures. London : The Guilford Press. 